lated to benefit the district dealt with, and which, instead of insulting the practical man, gives him information which he gladly utilises. The Report commences with a general discussion upon the composition, mode of formation, and the properties of soils, and the changes produced by cultivation. In the second section, soil in its relation to vegetation is somewhat elaborately dealt with. In the third section, soil in its relations to animal life is very completely presented to the reader's attention. The question of the absorptive powers of soils is ably dealt with. "As to the cause, opinions vary, but closer study of the phenomena of absorption have led back to the pretty general acceptance of the explanation originally offered by Way, which, as expressed by Mayer ('Agrikultur Chemie'), is as follows:- "We find in the soil easily decomposable double silicates, the exact composition of which is unessential, which, along with alumina, always contain some other base, an alkali or an alkaline earth, or even several of these bases at the same time. These silicates have the property, under certain conditions, of exchanging their accessory ingredients (not the alumina). The artificial silicate of Way had the composition of a zeolite, and it remained only to experiment with naturally occurring zeolites, which was done by Eichhorn, Mulder, and others, with the result of showing ... that they all possess the power of exchanging a portion of their original content of lime or soda for an equivalent of potash or ammonia ; in other words, of absorbing the latter bases. . . . According to Mulder ... while the fertility of soil does not depend exclusively upon these zeolites, yet its chemical activity is altogether determined therebv." These comments are the more noteworthy because there has been a tendency amongst some chemists to undervalue the importance of Way's discovery, but the testimony of practice is too strong for it to be altogether ignored.

An exceedingly important connection is shown between the production of cotton and the systems of management pursued in Alabama. Speaking of the Great Cotton Belt of Alabama, the Report points out that the soils upon this belt have been largely exhausted by improvident culture, cotton being planted year after year upon the same soils, without any attempt being made to maintain the fertility by the use of manures. In other parts of the State where cotton is produced a selection is generally made of the better soils, rotation of crops is more generally practised, and in some sections fertilisers are in more general use. This is largely occasioned by the relative proportions of the population and the capital they have at their command.

"The system of credits in the large cotton-producing regions prevails to such an extent that the whole cotton crop is usually mortgaged before it is gathered, and when we consi ler that the prices charged for provisions are at least 50 per cent. higher than regular market rates, ... it will need very little calculation to show that the labourer will have the chances too greatly against him, even to be out of debt to his merchants, when he relies solely upon this crop to provide the money, and the exorbitant interest on the money advanced is not likely to be lessened so long as the merchants' risks continue to be as great as they are. Where the blacks are in excess of the whites there are the originally most fertile lands of the State. The natural advantages of the soils are, however, more than counterbalanced by the bad system prevailing in such sections, viz. large farms rented out in patches to labourers, who are too poor and too much in debt to merchants to have any interest in keeping up the fertility of the soil, or rather they lack the ability to keep it up, with the natural consequence of its rapid exhaustion and a product per avre on the best lands in the State Jower than that which is realised from the very poorest. Where the two races are in nearly equal proportions ... there is found the system of small farms, worked gene- rally by the owners, a consequently better cultivation, a more general use of commercial fertilisers, a corresponding high product per acre, and a partial maintenance of the fertility of the soils."

The entire Report is literally crowded with interesting and most important details, such as skilled experts are likely to formulate for the guidance of higher officials and for the assistance of those engaged in the cultivation of the land. The well-organised system existing in the United States, whereby the causes of failure and success are rendered prominent, is doing great service to that country, for they clearly recognise the truth that the advancement of agriculture is a national duty, because just in proportion as additional wealth is thus created within the States, so do the people generally participate in the advantages thus secured.

\section{BIRD SKELETONS}

THE author of this important work, shortly after his return from his explorations in New Guinea and the Moluccas, was appointed Director of the Royal Zoological Museum at Dresden, and under his care the last-named museum is fast becoming one of the leading institutions in Germany. During his travels in the East Dr. Meyer appears to have amassed a considerable amount of material for his projected work on the skeletons of birds, and now that five parts of the "Abbildungen" have appeared, we think it well to draw the attention of English naturalists to it, as it will undoubtedly prove to be one of the most interesting osteological works yet attempted. The skeletons are all contained in the Dresden Museum, and Dr. Meyer proposes to carry on the work until his material becomes exhausted; but we trust that all ornithologists who can aid the author in his excellent enterprise will not fail to do so.

The works on the osteology of birds are not numerous, and this important portion of ornithological study has been too much neglected and systematically overlooked. The chief English work has been the "Osteologia Avium " of the late Mr. Eyton, and there are, of course, Prof. Owen's well-known memoirs on the Dinornis and its allies, on the Great Auk, and a few scattered representations of skeletons here and there. France can boast of Prof. Milne-Edwards's splendid volumes on fossil birds in comparison with recent forms, as well as the fine series of illustrations in the "Histoire Naturelle de Madagascar" of M. Grandidier. In Germany Prof. Selencka, of Erlangen, commenced, in Bronn's "Classen und Ordnungen," a systematic treatise on the osteology of birds, but unfortunately he discontinued this useful work after the issue of a few parts. Dr. Meyer's labours therefore deserve the acknowledgment of all scientific men as being an attempt to fill up a gap in our knowledge of birds. There are probably eleven thousand species of birds described up to the present time, but the osteological characters of only a very small proportion of them have been noticed, and a very inconsiderable number of the three thousand genera have been illustrated. As Dr. Meyer only firures those species which have not been before represented, each illustration represents a new fact: for science, and we trust that he will be able to continue to add to the already rich materials at his commant, and bring to a successful conclusion the important task which he has set himself.

Dr. Meyer does not avail himself of the usual mode of illustration by lithography, but has had all the skeletons photographed from nature, and then reproduced by

I "Abbjlaungen von Vogel-Skeletten herausgeben mit Unterstützung der generaldirection der konigl, Sammlnngen für Kunst und Wissenschaft in Dresden." Von Dr. A. B. Meyer. Parts I to 5 , pp. I to 40 , Plates 1 to 50 (Dresden: Published by the Author, $1879-188_{3}$.) 
phototype. This process does not fade as a photograph is liable to do, but has the consistency of print with the appearance of a steel engraving. By an ingenious method adopted by the author only one side of the bird's skeleton is given in the plate, and thus the confusion which is often seen in osteological illustrations from the appearance of the opposite side of the skeleton in the picture is obviated. The plates, which have been executed in Dresden at Mr. Wilhelm Hoffmann's Art Institute, de. serve great credit for their execution. The letterpress which accompanies the figures gives the distinguishing characters of the skeletons with their principal measurements.

It is proposed to issue at least two parts in the course of every year, each part to contain ten plates. Out of the number hitherto published we find illustrations of seventeen Parrots belonging to fourteen genera, amongst them being the rare Dasyptilus pesqueti from $\mathrm{New}$ Guinea, the smallest known Parrot, Nasiterna pygmaa, as well as the largest one, Microglossus aterrimus, both of which are from New Guinea; Nestor meridionalis and Stringops habroptilus from New Zealand, besides illustrations of members of the following genera:-Eclectus, Cacatuct, Cyclopsitta, Ioriculus, Trichoglossus, Charmosyna, Brotogerys, Tanygnathus, and Eos. Of Birds of Paradise iliustrations are given of Cicinnurus regius, $P$ aradisea minor, Manucodia chalybeata with its twisted windpipe, along with those of its allies. Other Birds of Paradise are promised by Dr. Meyer. Among the Pigeons are figured species of Carpophaga, Otidiphaps, Edirhinus and Ptilopus, side by side with skeletons and skulls of some of the domestic races. Of Kingfishers figures of the skeletons of the genera Cittura, Tanysiptera, and Samromarptis are furnished, and among others we find illustrations of such interesting genera as the following:-Pelenopides, Meropogon, Collocalia, Heteralocha, Rallina, Scissirostrum, Streptocitto, Oriolus, Dicrurus, Lepidogrammus, \&c.

We must draw the special attention of our readers to the skeleton of a species of Notornis from New Zealand, which Dr. Meyer has figured in Plates 34 to 37 . This skeleton was procured along with the skin of the bird in South Island, N.Z., in the year 1879 , and has found its way to the Dresden iMuseum. Complete figures of the osteology of this interesting genus are here given for the first time. Our national collection contains two skins of Notomis, but no skeleton, only some fossil remains from the North Island having been described and figured in the year 1848 by Prof. Owen. From a comparison of the latter with the skeleton now in the Dresden Museum, Dr. Meyer has been induced to consider that the North Island species is distinct from that inhabiting the South Island, and as the name of Notornis mantelli was given by Owen to the former bird, the specimen in the British Museum which came from the South Island must bear the name of Notomis hochstetteri, as Dr. Meyer proposes to attach to it the name of the well-known New Zealand explorer, Prof. von Hochstetter of Vienna.

A comparison is instituted by Dr. Meyer between the skeletons of different species of Porphyrio and Ocydromus. Together with the skeleton of the Jungle-fowl (Gallus bankiva), which Dr. Meyer himself brought from Sangi Island, north of Celebes, and different species of grouse (amongst them that of Tetrao medius), we find representations of the skeletons of several domesticated races of fowls. The importance of the characters presented by the differences of the crania and other portions of the skeletons of domestic fowls and pigeons was long ago proved by Mr. Darwin, and as there were only certain portions of the skeletons figured by him, the material which Dr. Meyer has collected with great care offers to the student a better opportunity of going deeply into this subject.

R. B. S.
THE "POTETOMETRE," AN INSTRUMENT FOR MEASURING THE TRANSPIRATIUN OF WATER BY PLANTS

$\mathrm{I}$ view of the interest now attaching to recent advances in vegetable physiology, it secms not unlikely that a description of the instrument bearing the above name, lately published by Moll (Archives Néerlandaises, t. xviii.), will serve a useful purpose. ${ }^{1}$ The apparatus was designed to do away with certain sources of error in Sachs's older form of the instrument, described in his "ExperimentalPhysiologie "-errors chiefly due to the continual alteration of pressure during the progress of the experiment.

As shown in the diagram, the "potétomètre" consists essentially of a glass tube, $a d$, open at both ends, and blown out into a bulb near the lower end ; an apcrture also

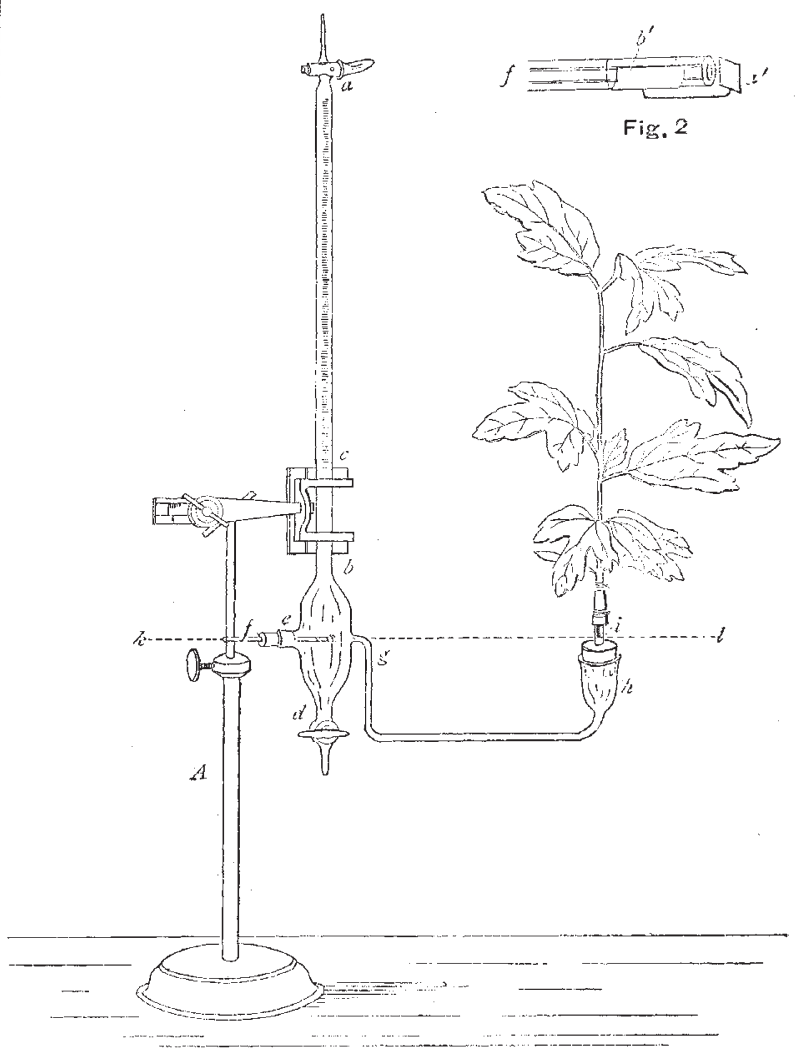

Fig. I

exists on either side of the bulb at or about its equator. The two ends of the main tube are governed by the stopcocks $a$ and $d$, and the greater length of the tube is graduated. A perforatcd caoutchouc stopper is fitted into one aperture of the bulb $\varepsilon$, and a tube, $g^{h}$, fits hermetically to the other. This latter tube is dilated into a cup at $h$ to receive the caoutchouc stopper, into which the end of the shoot to be experimented upon is properly fixed.

The fixing of the shoot is effected by caoutchouc and wire or silk, as shown at $i$, and must be performed so that the clean-cut end of the shoot is exactly at the level of a tube passing through the perforated stopper, $e$, of the bulb; this is easily managed, and is provided for by the bending of the tube $g h$. The tube $f$, passing horizontally through the caoutchouc stopper $e$, is intended to admit bubbles of air, and so equalise the pressure and at the same time afford a means of mcasuring the rapidity of the absorption of water by the transpiring shoot. This tube

I Especially also with reference to Mr. F. Darwin's description of his
own ingenious instrument (see Natuse, May 